\title{
AKTYWNOŚCI STYMULUJĄCE REFLEKSJĘ W NAUCZANIU JĘZYKA PISANEGO W WIRTUALNEJ KLASIE
}

\author{
Activities stimulating reflection in teaching writing in a virtual \\ learning environment
}

The paper aims to show how to engage students attending an online language course in various activities which by stimulating reflection enhance the learning process and result in better learning outcomes. By blending cognitivist, constructivist, constructionist and behavioural ideas, course developers and tutors can produce materials and use methods which satisfy the varied needs of adults who want to improve their writing skills. Such a blend leads to a unique design, which can be achieved by tools available in a virtual learning environment. Course participants will be more adequately prepared for writing genuine texts in the future through use of such activities as working with authentic resources integrated with different tasks and assignments to stimulate reflection; studying under the supervision and guidance of the tutor; participating in collaborative projects to promote learner autonomy; developing new knowledge through meaning-making discussions; doing peer review as well as summative, formative assessment, and selfassessment. Experience of these ways of working will help the participants to eventually become self-regulated, lifelong learners.

Keywords: VLE, reflection, constructivism, FLT, writing skill

Słowa kluczowe: VLE, refleksja, konstruktywizm, nauczanie języków obcych, język pisany 


\section{Wprowadzenie}

Istotnym aspektem uczenia się języka obcego przez osoby dorosłe jest dostosowywanie nowej wiedzy do już posiadanej, wytworzonej w wyniku kumulacji doświadczeń życiowych. Większość studentów, szczególnie starszych lat, na ogół dobrze rozumie swoje przyszłe zawodowe potrzeby i życiowe pragnienia, które już w czasie studiów stymulują ich zainteresowania. Posiadają oni także własne nawyki uczenia się, co może powodować, że będą odnosić się z rezerwą do nieznanych im wcześniej metod uczenia się języka obcego. Ponadto $w$ życiu codziennym otaczają się różnymi technologiami, które wykorzystują między innymi do komunikacji, zdobywania informacji, autoprezentacji, wymiany poglądów, zawierania znajomości i uprzyjemnienia sobie czasu wolnego. Wiele narzędzi internetowych $i$ aplikacji wciąga młodych ludzi w wirtualny świat pełen atrakcji, w którym potrafią lepiej funkcjonować niż w rzeczywistości realnej (Castronova, 2010; Bartle, 2010; Boellstorff, 2010). Sposoby zdobywania wiedzy i polepszania umiejętności, które preferują młodzi ludzie, oraz narzędzia wykorzystywane przez nich w tym celu, powinny więc być wzięte pod uwagę przy opracowywaniu efektywnego kursu nauki pisania tekstów w języku obcym, a szczególnie w języku angielskim, bowiem jest on głównym medium komunikacyjnym pozwalającym na sprawne wykorzystywanie zasobów internetowych.

Celem niniejszego artykułu jest odpowiedź na pytanie, jak przy pomocy różnorodnych aktywności pobudzić studentów do refleksji na kursie internetowym, dzięki której będą w stanie efektywniej uczyć się języka obcego i zdobyć umiejętności dalszego samokształcenia. Analiza możliwości stwarzanych przez strukturę kursów online i narzędzia dostępne w oprogramowaniach do zarządzania nimi została dokonana na podstawie rozważań teoretycznych zawartych w literaturze przedmiotu oraz na bazie doświadczeń zebranych przez autorkę $w$ czasie prowadzenia semestralnych internetowych kursów nauki języka angielskiego pisanego w latach 2008-2013.

\section{Podstawy teoretyczne tworzenia kursu e-learningowego dla dorosłych}

Trzy teorie - andragogika, uczenie transformacyjne oraz teoria krytycznego myślenia - pozwalają na zrozumienie tego, jak uczą się dorośli. Pierwsza z nich podkreśla istotną rolę samoświadomości, doświadczenia, gotowości, motywacji i chęci do nauki oraz do rozwiązywania problemów. Według drugiej, dorośli ucząc się restrukturyzują swoją dotychczasową wiedzę. Dochodzą do nowych znaczeń analizując swoje doświadczenia i przetwarzając je w celu zaadapto- 
wania nowych treści. Krytyczne myślenie pozwala dorosłym samodzielnie rozwijać swoje umiejętności i kierować procesem edukacyjnym. Materiały kursowe powinny więc promować i ułatwiać samoregulację (Schraw, Crippen i Hartley, 2006: 111-139; Shuy, OVAE i TEAL, 2010), to znaczy umożliwiać i stymulować samorefleksję, samouczenie się, zwiększać motywację i zachęcać do refleksji, zarówno nad stroną merytoryczną, jak i językową, oraz aktywizować uczniów poprzez kooperację i kolaborację (Donelan, Kear i Ramage, 2010). Ważnym celem kursu językowego powinno być wyposażenie ucznia w narzędzia pozwalające mu uczyć się przez całe życie. Programy szkoleniowe stworzone w środowisku e-learningowym, wykorzystujące myślenie dialektyczne, logikę praktyczną, rozumienie posiadanej wiedzy i krytyczną refleksję, czyli zdolności, które posiada dorosły i przygotowane w oparciu o autentyczne źródła, będą bardziej skuteczne w rozwijaniu umiejętności językowych, a szczególnie umiejętności pisania tekstów. Ponadto umożliwią uczniowi zdobycie wiedzy przydatnej w późniejszym życiu zawodowym.

W nauczaniu dorosłych języka obcego, w tym języka pisanego, w środowisku e-learningowym widać zarówno wpływ konstruktywizmu (Piaget, 1969; Vygotsky, 1978) i konstrukcjonizmu (Papert i Harel, 1991), jak i kognitywizmu, czy nawet behawioryzmu. Wykorzystanie pewnych elementów tych teorii prowadzi do stworzenia efektywnego kursu zaspokajającego potrzeby językowe dorosłego ucznia. Podejście eklektyczne wzmacnia proces edukacyjny, a połączenie różnych idei, pochodzących ze wspomnianych paradygmatów, tworzy amalgamat skuteczny w nauczaniu zarówno w środowisku tradycyjnym, jak i w e-learningowym oraz w tzw. blended learningowym. Połączenie to jest najbardziej efektywne, gdy wykorzystane są następujące elementy:

$>$ behawiorystyczny sposób formułowania celów ogólnych i szczegółowych kursu, wzmocnienie pozytywne osiągnięte przez stymulację i wsparcie ze strony nauczyciela oraz poprzez ocenę formatywną;

$>$ analizy przeprowadzane przez językoznawstwo kognitywne odnoszące się do kategoryzacji naturalnej, modeli kognitywnych, podobieństwa rodzinnego i ekstensji metaforycznych, pozwalające zrozumieć system konceptualny rdzennych użytkowników języka angielskiego i lepiej go stosować w pisaniu tekstów;

$>$ konstruktywistyczne podejście do wykorzystania autentycznych materiałów i ich analiza z różnych punktów widzenia, aktywna rola ucznia w rozwiązywaniu problemów w ramach współpracy projektowej i dyskusji, ocenianie na podstawie zadań zmuszających ucznia do refleksji i pracy twórczej prezentującej zindywidualizowany punkt widzenia i testy zawierające pytania otwarte; 
$>$ konstrukcjonistyczne indywidualne podejście do ucznia, nacisk na kontekstualizację i tworzenie znaczeń w czasie wspólnego pisania tekstu, który będzie później wykorzystany na kursie, oraz na refleksję stymulującą proces tworzenia.

\section{Materiały statyczne i interaktywne pobudzające refleksję w wirtualnej klasie}

Projektanci zajęć e-learningowych typu online i blended wykorzystują różne oprogramowania do zarządzania kursami internetowymi. Obecnie najpopularniejszą platformą edukacyjną na uczelniach polskich i zachodnich, czyli wirtualnym środowiskiem uczenia się (VLE), jest oprogramowanie typu open source - Moodle. Umożliwia ono przygotowanie różnego typu zasobów i aktywności. Pierwsze obejmują strony internetowe z materiałami kursowymi, stworzone przez nauczyciela przy pomocy narzędzi dostępnych w systemie, linki do stron www oraz załączone do strony kursu pliki, np. w formacie doc, pdf lub w postaci prezentacji przygotowanych w programie PowerPoint. W skład aktywności wchodzą prace umieszczane przez studentów na stronie kursu i sprawdzane przez nauczyciela; zadania oceniane przez system, opracowane w formie quizów edukacyjnych i testów; chaty i fora dyskusyjne pozwalające na synchroniczną oraz asynchroniczną współpracę; ankiety i zapytania, umożliwiające nauczycielowi uzyskanie szybkiej informacji zwrotnej z opiniami studentów w każdym momencie trwania kursu; wiki, stwarzające warunki do prowadzenia zajęć opartych na kooperacji i kolaboracji oraz warsztaty, pozwalające studentom na współocenianie swoich prac. Oprogramowanie to, zwane także wirtualną klasą, zapewnia nauczycielowi wszechstronny monitoring pracy studentów na kursie, dzięki któremu ma on szybki wgląd w logi informujące o tym, kiedy każdy student łączył się ze stroną kursu, jakie zasoby otwierał i które zadania wykonywał. Nauczyciel może też sprawdzić wyniki ćwiczeń i testów, które zostały automatycznie ocenione przez system, skorygować je, jeśli zachodzi taka potrzeba, a także wysłać informacje do poszczególnych studentów, grupy lub wszystkich studentów jednocześnie.

Aby motywować studentów do pracy, kurs języka pisanego prowadzony całkowicie online lub w trybie blended powinien zawierać takie zadania, jak:

- krótkie pytania pozwalające na szybką samoocenę (SAQ) i na refleksję, przy czym obu typom nie powinny towarzyszyć odpowiedzi przygotowane wcześniej przez nauczyciela;

- zadania interaktywne, refleksyjne, kooperacyjne, kolaboracyjne, samooceniające i współoceniające, jak również bazujące na dyskusjach lub 
szybkiej wymianie poglądów, wykonywane pod nadzorem nauczyciela i przez niego sprawdzane lub monitorowane oraz oceniane przez system, na podstawie odpowiedzi wprowadzonych przez twórcę materiałów.

Nie tylko pytania nakierowane specjalnie na pobudzenie natychmiastowej refleksji i oznaczone w ten sposób, ale wszystkie wymienione wyżej aktywności mają zachęcać studentów do krytycznej refleksji. Polega ona na analizie poglądów wyrażonych w zamieszczonych w kursie tekstach i zrozumieniu ich historyczno-kulturowych kontekstów oraz na próbie znalezienia alternatywnych podejść do zaproponowanych wcześniej rozwiązań zadań teoretycznych i praktycznych. Za sprawą refleksyjnego sceptycyzmu, który jest ostatnim elementem krytycznej refleksji, dorośli uczniowie mogą dojść do modyfikacji wcześniejszych ustaleń lub do twórczego przetworzenia zastanej wiedzy w badanych przez siebie zjawiskach (Brookfield, 1988: 325-327).

Dzięki swoim funkcjonalnościom narzędzia internetowe dostępne w wirtualnym środowisku uczenia się oferują afordancje (Gibson, 1979: 127) zwiększające różnego typu umiejętności, których brak w tradycyjnym nauczaniu języka obcego w sali wykładowej (Weller, 2007: 120-123), gdzie wykorzystuje sie głównie materiały drukowane, takie jak teksty, ilustracje, diagramy, wykresy, tabele, schematy i zadania na nich oparte, przygotowane w formie pisemnej lub ustnej, oraz ćwiczenia zaprojektowane na bazie ścieżki dźwiękowej i obrazu filmowego. Tradycyjne materiały edukacyjne mogą zagwarantować osiągnięcie założonych celów kształcenia, jeśli studenci wykonają wszystkie zadania - zarówno te wprowadzone przez nauczyciela w czasie spotkania w klasie, jak i te przeznaczone do zrobienia później, które mają wzmocnić i rozwinąć umiejętności ćwiczone podczas zajęć. Ponieważ oprogramowanie do zarządzania kursami online umożliwia wszechstronny monitoring i wprowadzenie zadań o różnym poziomie interaktywności, to aktywności, w których studenci muszą brać udział, są bardziej motywujące i stymulujące do pracy. Uczący się wiedząc bowiem, że system pokazuje nauczycielowi, co i kiedy wykonują, czują się zobowiązani do odrobienia wszystkich prac i wzięcia udziału we wszelkich obowiązkowych zadaniach interaktywnych. Dlatego też komponenty e-learningowe, zawierające zróżnicowane zasoby i aktywności, zwiększają nakład pracy studenta, którą musi wykonać samodzielnie lub w grupie, a więc pobudzają go częściej do refleksji nad treściami edukacyjnymi, metodami rozwiązywania zadań umieszczonych $\mathrm{w}$ tym środowisku i nad samym uczeniem się. Refleksja jest bowiem niezbędnym aspektem uczenia się, potrzebnym do osiągnięcia samoregulacji i prowadzącym do rozwoju umiejętności zdobywania wiedzy przez całe życie. Praktyka refleksyjna (Schön, 1983: 128-167) pomoże studentom wykonywać zadania w sposób bardziej efektywny i fachowy, zwiększy ich samo- 
świadomość, doprowadzi do poszerzenia nabytej wiedzy i rozwoju profesjonalnego oraz do większej efektywności organizacyjnej (Osterman, 1990: 133-152; Osterman i Kottkamp, 1993: 18-42).

\subsection{Materiały informacyjne, czyli zasoby}

Strony www z materiałami kursowymi należące do zasobów, czyli bardziej statycznych form przekazywania treści edukacyjnych, powinny zawierać zadania do refleksji, które muszą dzielić lity tekst informacyjny. Ich celem jest, po pierwsze, skupienie uwagi ucznia na wykonywanej pracy; po drugie, pokazanie mu, co powinien wiedzieć z materiału, który sam przeczytał, jak trzeba interpretować omówione zagadnienia i jak rozumieć kontekst, w jakim one się pojawiają; po trzecie, zachęcanie studenta do modyfikowania zdobytej wiedzy i wyciągania własnych wniosków, które mogą przyczynić się do stworzenia przez niego własnej interpretacji i dojścia do innych znaczeń. Nie wprowadza się tych zadań, by przetestować umiejętności zdobyte przez ucznia wcześniej lub w czasie trwania kursu, dlatego nie powinno się dołączać do nich odpowiedzi sugerujących poprawny tok myślenia.

Trzeba je tak sformułować, by uczący się wykonując je, poczuł się zachęcony do głębszych przemyśleń, które bardziej go zaangażują w proces edukacyjny. Dobrą praktyką jest, gdy tekst informacyjny, widoczny na ekranie, podzielony jest jednym zadaniem do samorefleksji, które jest wprowadzone inną czcionką lub kolorem za pomocą specjalnie zaprojektowanego szablonu, zawierającego zawsze ten sam znak graficzny, przyciągającego uwagę czytającego. Zarówno struktura tekstów z aktywnościami tego typu, jak i forma tych aktywności muszą być dokładnie przemyślane, bowiem jeśli student uzna, że dany materiał jest przeładowany zadaniami do refleksji lub że są one niezrozumiałe, nieadekwatne albo nudne, zapewne nie wykona ich, uznając, że poświęcenie im uwagi będzie stratą czasu. W ten sposób jeden z celów jednostkowych, polegający na aktywizacji studentów, zachęceniu ich do pogłębionej analizy, której efektem ma być tworzenie nowych znaczeń, nie zostanie zrealizowany.

W kursie internetowym poświęconym rozwojowi umiejętności pisania tekstów w języku obcym zadania do refleksji mogą pojawić się w materiałach teoretycznych dotyczących używania języka obcego pisanego, poruszających takie zagadnienia jak np. cechy gatunkowe, styl, koherencja, kohezja i rejestr, używanie metafor, pisanie spójnych logicznie paragrafów, wplatanie w nie danych, dokumentowanie obcych źródeł. Powinny one być zawarte także w materiałach analizujących przykładowe teksty, uczących znajdowania argumentów, tworzenia opisów, budowania narracji lub zarysowujących tematykę prac, które 
student będzie musiał przesłać do oceny. Forma językowa zadań do refleksji może być zróżnicowana i powinna oczywiście zależeć od typu informacji, z którą student właśnie zapoznał się na specjalnie zaprojektowanej stronie kursu wprowadzającej zagadnienia teoretyczne. Przy tworzeniu zadań do samorefleksji, bez względu na treść materiału, którego dotyczą, nauczyciel musi wziąć pod uwagę umiejętności językowe uczącego się i poziom jego rozwoju intelektualnego oraz sformułować je w sposób jasny, prosty i zwięzły. Tylko tak zaprojektowane zadania będą stymulowały go do głębszych przemyśleń.

\subsection{Materiały interaktywne, czyli aktywności}

Materiały edukacyjne zaprojektowane na potrzeby komponentu e-learningowego i umieszczone w internetowym systemie do zarządzania kursami, takim jak Moodle, powinny zawierać różnego typu aktywności, tj. dłuższe i krótsze zadania interaktywne, które zwiększają zaangażowanie studentów w wykonywaną pracę. Pozwolą im one osiągnąć zamierzone efekty kształcenia poprzez zrealizowanie celów zarówno ogólnych dla danego kursu i modułu, jak i jednostkowych, wyznaczonych dla poszczególnych jego elementów. Istnieje wiele typów zadań, które pomogą studentom rozwinąć umiejętność poprawnego pisania w języku obcym i tworzenia tekstów autentycznych (Wenzel, 2001: 96108). Obejmują one zadania refleksyjne, aktywne, dialogiczne, oparte na kolaboracji i kooperacji (Heriot-Watt University, 1999, module 2a: 27). Wszystkie mogą być wykonywane drogą synchroniczną lub asynchroniczną.

Zadania oznaczone przy pomocy wybranego systemu graficznego jako refleksyjne można wprowadzać poprzez ankiety, zapytania, informacje zwrotne na różnych etapach kursu nauki pisania w JO - w trakcie trwania modułów jako ćwiczenia przygotowujące do precyzowania argumentów potrzebnych do napisania tekstów zaliczeniowych oraz po zakończeniu modułu lub kursu jako ćwiczenia analityczne, których celem jest refleksja nad wykonanymi pracami i ocenami formatywnymi przesłanymi przez nauczyciela. Jeśli tekst zaliczający dany moduł nie spełnia założonych kryteriów jakości, w informacji zwrotnej nauczyciel może zasugerować np. rozważenie innych aspektów opisywanego zagadnienia lub przeanalizowanie tematu w odmienny sposób albo przemyślenie zmiany struktury argumentów lub całego tekstu. Zachęcenie uczącego się do refleksji nad pracami, które napisał, i wskazanie mu tylko problemów, które powinien rozważyć, bez podania poprawnych odpowiedzi, szczególnie gdy takich jest wiele i są one zależne od punktu widzenia, będzie bardziej stymulujące do pracy i wytrwania na kursie internetowym. Niektóre odpowiedzi do zadań refleksyjnych, które należą do aktywności, czyli do bardziej interaktywnej części kursu, a nie do zasobów, szczególnie na te, które uczą studentów, jak popraw- 
nie logicznie, stylistycznie i językowo konstruować tekst, mogą być wcześniej opracowane przez nauczyciela. Jeśli zostały przygotowane, to powinny być załączone w odpowiednim miejscu na stronie kursu - albo obok pytań, albo w specjalnym pliku umieszczonym w innym miejscu, np. na stronie głównej, o istnieniu którego studenci muszą zostać poinformowani.

Pozostałe typy zadań, tj. zdania aktywne, dialogiczne oraz oparte na kolaboracji i kooperacji, do których przygotowania używa się w środowisku Moodle narzędzi z grupy aktywności, też mogą zawierać punkty do refleksji. Ich głównym celem jest wciągnięcie studentów w różnego typu interakcje, mające na celu zaktywizowanie ich poprzez wymianę poglądów, współpracę, współocenianie i refleksję zarówno nad wykonywanymi pracami, jak i nad własnymi umiejętnościami, osiągnięciami, brakami lub potrzebami. Tego typu refleksja pozwoli im stać się uczniami samoregulacyjnymi, potrafiącymi samodzielnie rozwijać swój warsztat w dalszym życiu zawodowym. Do stworzenia wymienionych powyżej zadań wykorzystuje się chaty, fora dyskusyjne, wideokonferencje, blogi, wiki i warsztaty, czyli narzędzia dostępne np. w oprogramowaniu Moodle, pomagające studentom uczestniczyć w zajęciach grupowych, dzięki którym pracując na kursie online lub wykonując komponent e-learningowy kursu typu blended nie czują się osamotnieni i wyizolowani ${ }^{1}$.

\subsubsection{Chat}

Narzędzie, dzięki któremu studenci mogą prowadzić synchroniczne rozmowy i dyskusje to chat. Doskonale nadaje się do wprowadzenia zadań dialogicznych. Nauczyciel może zadać parom uczniów różnego typu ćwiczenia polegające na wymianie poglądów, opinii i przygotowaniu planu zadania pisemnego. Ponieważ komunikacja synchroniczna, w którą studenci w ten sposób zostaną zaangażowani, będzie skutkowała produkcją tekstów pisanych stylem nieformalnym, przypominać ona będzie nieformalne rozmowy w czasie lekcji, mające miejsce

\footnotetext{
${ }^{1}$ Analizy ankiet uczestników kursów e-learningowych, przedstawiane w literaturze fachowej (Willging i Johnson, 2004) pokazują, że jedną z przyczyn niechęci do tego typu zajęć i wysokiego odsetka rezygnacji z nich jest to, iż uczącym się brakuje kontaktu z rówieśnikami. Czują się wyizolowani i osamotnieni wykonując zadania kursowe, których jest więcej i są bardziej zróżnicowane w porównaniu z pracami zadawanymi do wykonania po zajęciach tradycyjnych. Kursy online poświęcone nauczaniu języka obcego pisanego, w których kładzie się nacisk jedynie na pracę indywidualną, będą skuteczne tylko w przypadku bardzo zmotywowanych studentów, posiadających umiejętność samoregulacji. Uczniom, u których taka zdolność jeszcze nie wykształciła się, trzeba stworzyć warunki przypominające do pewnego stopnia te, które panują w tradycyjnej sali wykładowej, gdzie możliwe są wszelkiego typu interakcje pomiędzy uczestnikami zajęć.
} 
w trakcie np. opracowywania tematów zadań pisemnych, wymyślania historyjek, interpretacji zdarzeń czy znajdowania argumentów za i przeciw.

Na kursie e-learningowym komunikacja synchroniczna charakteryzuje się pewną wartością dodaną - $w$ czasie jej trwania studenci porozumiewają się w języku obcym, a nie w ojczystym, jak to często bywa w klasie, gdy nauczyciel zadaje zadania dialogiczne, oraz piszą swoje wypowiedzi, a więc ćwiczą język pisany. Robiąc to, muszą myśleć o regułach ortograficznych, poprawnym budowaniu zdań, odpowiednim dobieraniu słownictwa i konstrukcji oraz adekwatnym wyrażaniu poglądów, bowiem nauczyciel może sprawdzić, jak zadanie, które zadał jest wykonywane i je skomentować. Aktywności tej powinna towarzyszyć refleksja polegająca na reagowaniu na treść zadania i jego omówieniu, czyli przedstawieniu uczuć, zweryfikowaniu sposobów myślenia, zrobieniu odniesień do innych sytuacji i dawaniu przykładów (Surbeck, Han i Moyer, 1991: 21-27).

\subsubsection{Forum dyskusyjne}

Fora dyskusyjne służą do prowadzenia komunikacji asynchronicznej, która ma miejsce dzięki wprowadzaniu zadań refleksyjnych, dialogicznych, aktywnych i wymagających współpracy w ramach projektów zespołowych. Nauczyciel może zachęcić studentów do publikowania na nich efektów swoich poszukiwań lub badań, które później mogą być wykorzystane do pisania różnych tekstów, takich jak artykuły czy raporty, lub do używania ich jako narzędzi do zadań dialogicznych i aktywnych, czyli do komunikacji i współoceniania prac koleżanek i kolegów (Bender, 2012: 191-193). Dyskusje prowadzone w ten sposób są bazą tekstów autentycznych i autentycznych interakcji, w których studenci prezentują swoje poglądy, przemyślenia, refleksje i wiedzę oraz dzielą się z innymi doświadczeniami zdobytymi np. w czasie poszukiwania wiadomości lub rozwiązań problemów związanych z zagadnieniami poruszonymi wcześniej przez nauczyciela lub innych uczestników kursu. Fora mogą też być wykorzystane do gromadzenia danych zebranych przez studentów w czasie prac grupowych, które posłużą później do głębszej refleksji potrzebnej do pisania analiz czy innych prac akademickich.

Nauczyciel nadzorujący zadania na forum to moderator ${ }^{2}$, który ustala tempo pracy, wspiera studentów, zwłaszcza tych słabszych, którzy nie są

\footnotetext{
${ }^{2}$ Według wielu twórców kursów internetowych (Jordan, Carlile i Stack, 2008: 194), nauczyciel powinien dawać wskazówki uczniom, jak uczestniczyć w zadaniach komunikacyjnych, ustalać tematykę dyskusji, zachęcać studentów do refleksji nad swoimi odkryciami i osiągnięciami, pomagać im w rozwiązywani problemów, pokonywaniu trudności, definiować obszary problematyczne oraz pokazywać różne punkty widzenia na omawiane na forum kwestie, a także pogłębiać ich rozumienie.
} 
szczególnie aktywni i którzy wymagają ciągłej zachęty i działań motywujących. Jeśli tacy uczniowie przyzwyczają się do używania forów do przedstawiania efektów swojej pracy lub przemyśleń, będą bardziej skłonni do brania udziału w spontanicznych dyskusjach i zdaniach dialogicznych nie bazujących na komentowaniu wcześniej przygotowanych materiałów lub wyrażaniu wcześniej sformułowanych opinii. W ten sposób poprzez zadania pisemne mogą poprawić swoje umiejętności komunikacyjne.

\subsubsection{Wiki}

Dwa typy zadań, tj. kolaboracyjne, oparte na ścisłej współpracy na każdym etapie i wspólnym wykorzystywaniu materiałów zgromadzonych przez poszczególnych członków zespołu już w czasie pracy etapowej, oraz kooperacyjne, w których uczestnicy wykonują powierzone im zdania i na koniec łączą efekty swoich badań, poszukiwań oraz swoje refleksje w celu przygotowania wspólnej pracy, mogą być realizowane nie tylko poprzez fora dyskusyjne, ale także dzięki wiki (Can, 2009). Narzędzie to umożliwia współredagowanie tekstu, a więc stwarza warunki do współpracy i wspólnej nauki. Uczniowie mogą się wzajemnie stymulować do refleksji i pogłębionej analizy, bowiem mają okazję twórczo rozwijać pomysły, wcześniej przedstawione przez swoje koleżanki i kolegów.

Dzięki współtworzeniu tekstu studenci uczą się też uważnie czytać wprowadzone już fragmenty, wyciągać wnioski i aplikować nowe rozwiązania. Bez stałej praktyki refleksyjnej osiągnięcie zadawalającego efektu końcowego nie będzie możliwe. Nauczyciel zadając pracę, która ma zostać napisana przy pomocy wiki, ma okazję monitorować postępy wszystkich uczestników. Z łatwością zauważy więc tych, których umiejętności językowe są niewystarczające lub tych, którzy nie potrafią analizować i komponować tekst adekwatny do tematu zadania. Dla nich będzie mógł stworzyć dodatkowe struktury wsparcia reaktywnego (Mokwa-Tarnowska, 2008).

\subsubsection{Blog}

Przy pomocy narzędzi dostępnych w wirtualnej klasie studenci mogą tworzyć blogi i wykorzystywać je do opracowywania e-portfoliów (JISC, 2007: 32), które dają szansę zaprezentowania wiedzy, którą zyskali, umiejętności, które zdobyli i zdolności do samorefleksji, którą rozwinęli w sobie (Brandes i Boskic, 2008; Anglia Ruskin University, 2010). Pisanie takich zbiorów tekstów zachęca uczniów też do refleksji nad tym, do czego posłużą im one w przyszłości i jak powinny być skonstruowane, by uwypuklać wszystkie zalety 
twórcy. Blogi stymulują również do refleksji tych uczniów, którzy je czytają, komentują i oceniają. Rozwijają więc u nich myślenie krytyczne i analityczne.

Pisząc e-portfolia studenci zwracają większą uwagę na poprawność językową i styl, szczególnie wtedy, kiedy wiedzą, że będą mogli je wykorzystać w przyszłości do celów profesjonalnych, publikując je na ogólnie dostępnych stronach. Tworzenie tego typu blogów może więc być zadaniem bardziej motywującym niż pisanie tekstu na zadany temat, może być pracą wzmacniającą poczucie własnej wartości.

W czasie trwania kursu języka obcego pisanego opracowywanie e-portfoliów przyniesie pozytywne efekty, jeśli nauczyciel zachęci uczestników do umieszczania w nich regularnych wpisów. Powinny one być wynikiem np. przemyśleń dotyczących zadań refleksyjnych umieszczonych w zasobach, które mają na celu między innymi zwiększenie zaangażowania i koncentracji.

\subsubsection{Warsztat}

Warsztat, narzędzie oprogramowania Moodle, umożliwia wprowadzenie zadań, które polegają na samoocenianiu i współocenianiu prac (Lamy i Hampel, 2007: 96). Pomagają one studentom poszerzyć i lepiej przyswoić wiedzę, którą muszą wykorzystać, by poprawnie ocenić swoje własne prace i zadania napisane przez innych uczestników kursu. Aktywność tego typu rozwija umiejętność myślenia refleksyjnego, analitycznego i krytycznego.

Zmiana procedur oceniających z tych, w których autorstwo wszystkich ocen formatywnych i sumatywnych należy wyłącznie do nauczyciela, na te, w których część ocen stawiają sami studenci, powoduje, że zwiększa się zaangażowanie uczącego się, co prowadzi do lepszych efektów kształcenia.

\section{Wnioski}

Wszystkie opisane wyżej aktywności wymagają nie tylko od studentów, ale także od nauczyciela nadzorującego pracę kursantów, dużego zaangażowania w proces edukacyjny. Wirtualna klasa umożliwia wszechstronną komunikację i interakcję między wszystkimi składnikami procesu edukacyjnego: uczniami, nauczycielem, technologią oraz zasobami i zadaniami. Dlatego dzięki informacjom na temat trudności, które napotykają uczący się, pochodzącym od użytego oprogramowania, nauczyciel może szybko zmodyfikować materiały kursowe - wprowadzić dodatkowe wyjaśnienia i ćwiczenia, jeśli są one niezrozumiałe lub zbyt trudne, rozszerzyć treści i dodać zadania, jeśli są mało motywujące 
i aktywizujące. Oczywiście, każda zmiana musi być spowodowana refleksją nad skutkami, które ona wywoła i tym jak wpłynie na efekty kształcenia.

Ocenianie w sposób formatywny pytań i zadań otwartych, które z punktu widzenia konstruktywizmu i konstrukcjonizmu pozwalają lepiej rozwinąć umiejętności językowe ucznia, skłania nauczyciela do ciągłej refleksji nad wieloma aspektami sprawdzanych przez niego prac. Dzięki przemyśleniom, do których nauczyciel dochodzi w trakcie trwania kursu, informacje zwrotne, zapisywane przez niego w systemie, mogą być też wykorzystane do pracy z innymi uczniami na innych kursach, mogą one stanowić bazę danych, np. na temat wzorcowych prac pisemnych.

Ucząc się pisania tekstów w języku obcym w środowisku e-learningowym, studenci ćwiczą nie tylko kompetencje językowe, ale także rozwijają umiejętność oceniania, zdolność do refleksji i samorefleksji oraz do rozpatrywania problemów z wielu punktów widzenia, kształcą myślenie analityczne i krytyczne, a także doskonalą umiejętność pracy w zespole. Kursy internetowe z powodu konstrukcji, wyglądu stron, typu materiałów i zadań oraz nawigacji mogą zachęcać uczniów do nauki i interakcji lub ich zniechęcać. Tylko właściwa równowaga między wszystkimi komponentami - tj. między zasobami wprowadzającymi treści teoretyczne i tematykę prac pisemnych, w które włączono różnego typu pytania i zadania otwarte zachęcające do refleksji, oraz aktywnościami, które skonstruowano za pomocą narzędzi pozwalających na umieszczenie w kursie zadań opartych na komunikacji i interakcji i rozwijających wyżej wspomniane sprawności - doprowadzi do pozytywnych efektów edukacyjnych.

Stworzenie właściwego środowiska, wciągającego uczestników w różnego typu interakcje, jest szczególnie ważne w przypadku kursów e-learningowych, gdyż nieaktywność kursantów, często spowodowana brakiem zainteresowania oraz mało angażującymi i motywującymi zadaniami kursowymi, prowadzi do wykonania prac, które nie spełniają wymogów jakości, bądź do niewykonania ich wcale lub rezygnacji z kursu.

Wszystkie opisane wyżej sposoby aktywizowania studentów pozwalają na zwiększenie ich zaangażowania i na osiągnięcie założonych efektów kształcenia. Stymulują one zarówno uczących się, jak i nauczyciela do refleksji. Ich przydatność w rozwijaniu refleksyjnego podejścia do sprawności pisania zależy od tematyki kursu, umiejętności językowych kursantów, ich wieku, preferencji w zakresie wyboru narzędzi internetowych, umiejętności komputerowych a także sprawności intelektualnej. O doborze odpowiednich zadań pobudzających refleksję powinni decydować twórcy kursów e-learningowych i nauczyciele nadzorujący je. Oni bowiem wiedzą najlepiej, które z omówionych praktyk refleksyjnych najbardziej przyczynią się do rozwoju umiejętności językowych swoich kursantów. 
Wirtualne środowisko nauczania daje projektantowi i nauczycielowi prowadzącemu zajęcia możliwość spersonalizowania treści kształcenia, zindywidualizowania ścieżek edukacyjnych, stworzenia zajęć opartych na konstruktywistycznym budowaniu znaczeń w czasie autentycznych dyskusji, w których biorą udział uczniowie i nauczyciele restrukturyzujący swoją wcześniejszą wiedzę poprzez zastosowanie praktyk refleksyjnych i oceniających.

\section{BIBLIOGRAFIA}

Anglia Ruskin University. 2010. http://www.ultraversity.net/ DW 6.08.2013.

Bartle, R. 2010. „Players” (w:) Online Communication and Collaboration (red. H. Donelan, K. Kear, M. Ramage). London: Routledge: 210-211.

Bender, T. 2012. Discussion-based Online Teaching to Enhance Student Learning: Theory, Practice, and Assessment. Sterling, Virginia: Stylus Publishing, LLC.

Boellstorff, T. 2010. „Everyday Second Life” (w:) Online Communication and Collaboration (red. H. Donelan, K. Kear, M. Ramage). New York: Routledge: 212-219.

Brandes, G. M., Boskic, N. 2008. „Eportfolios: From description to analysis”. The International Review of Research in Open and Distance Learning, June. http://www. irrodl.org/index.php/irrodl/article/view/502/1041 DW 21.11.2013.

Brookfield, S. 1988. „Developing critically reflective practitioners: A rationale for training educators of adults" (w:) Training Educators of Adults: The Theory and Practice of Graduate Adult Education (red. S. Brookfield). New York: Routledge: 325-327.

Can, T. 2009. „Learning and teaching languages online: A constructivist approach”. Novitas-ROYAL, 3(1): 60-74. http://www.ingilish.com/online-learning-constru ctivism. htm DW 20.11.2013.

Castronova, E. 2010. „The changing meaning of play” (w:) Online Communication and Collaboration (red. H. Donelan, K. Kear, M. Ramage). New York: Routledge: 204-209.

Donelan, H., Kear, K., Ramage, M. 2010. Online Communication and Collaboration. New York: Routledge.

Heriot-Watt University. 1999. Lola: Learning about Open Learning: Training Manual. Glasgow: Heriot-Watt University.

Gibson, J. J. 1979. The Ecological Approach to Visual Perceptions. Boston, MA: Houghton Mifflin.

JISC. 2007. Effective Practice with e-assessment. Bristol: JISC.

Jordan, A., Carlile, O., Stack, A. 2008. Approaches to Learning: A Guide for Teachers. Meidenhead: Open University Press.

Lamy, M-N., Hampel, R. 2007. Online Communication in Language Learning and Teaching. Basingstoke: Palgrave Macmillan.

Mokwa-Tarnowska, I. 2008. „Support mechanisms in teaching technical writing in the online environment" (w:) International Language Teaching Conference: Seeking most effective methods at different levels - organisation, methodology, tools (red. M. Chomicz, B. Trela). Warszawa: PWSBiA: 163-168. 
Osterman, K. 1990. „Reflective practice: A new agenda for education”. Education and Urban Society 22(2): 135-152.

Osterman, K. F., Kottkamp, R. B. 1993. Reflective Practice for Educators: Improving Schooling through Professional Development. Newbury Park: Corwin Press, INC.

Papert, P., Harel, I. 1991. Constructionism. New York: Ablex Publishing Corporation. http://www.papert.org/articles/SituatingConstructionism.html DW 6.08.2010.

Piaget, J. 1969. Mechanisms of Perception. New York: Basic Books.

Schön. D. 1983. The Reflective Practitioner: How Professionals Think in Action. Basic Books, Inc.

Schraw, G., Crippen, K. J., Hartley, K. 2006. „Promoting self-regulation in science education: Metacognition as part of a broader perspective on learning". Research in Science Education 36 (1-2): 111-139.

Surbeck, E., Han, E. P., Moyer, J. E. 1991. „Assessing reflective responses in journals” Educational Leadership 48(6): 21-27.

Shuy, T, OVAE i TEAL staff. 2010. Self-regulated Learning. TEAL Center Fact Sheet no. 3.

Vygotsky, L. S. 1978. Mind in Society. Cambridge, MA: Harvard University Press.

Weller, M. 2007. Virtual Learning Environments. New York: Routledge.

Wenzel, R. 2001. The Education of a Language Teacher. Gdańsk: Wydawnictwo Uniwersytetu Gdańskiego.

Willging, P. A., Johnson, S. D.. 2004. „Factors that influence students' decision to dropout of online courses". JALN 8(4): 105-118. 